\title{
Effects of glacier melting on socioeconomic development in the Manas River basin, China
}

\author{
Xiang-ling Tang $\cdot$ Li-Ping Xu $\cdot$ Zheng-Yong Zhang $\cdot$ Xin Lv
}

Received: 2 September 2012/ Accepted: 11 November 2012/Published online: 28 November 2012

(C) The Author(s) 2012. This article is published with open access at Springerlink.com

\begin{abstract}
This study used 46 years of recent data, including glacial area, temperature, precipitation, and runoff data, to examine the glacier melting and its possible socioeconomic effects in the Manas River basin in western China. The average yearly change in the glaciated area in the Manas River basin for the entire study period was $0.41 \%$, and the glacier mass balance mainly keeps negative in the last 46 years. The negative glacial mass balance observed between 1986 and 2006 was 2.8 times greater than that for the period 1960-1985. Additionally, the amount of meltwater runoff was $78 \%$ greater in 1986-2006 than in 1960-1985, with a mean depth of $478 \mathrm{~mm}_{\text {year }}{ }^{-1}$. Glacier melting and runoff in the Manas River basin during the late twentieth century were higher than at present. Annual meltwater volumes can reach $1 \times 10^{8} \mathrm{~m}^{3}$, providing beneficial water resources to downstream areas. However, as the climate becomes warmer, the risk of meltwater flooding will also increase. Our calculations indicate that after the 2030s, the level of flooding risk will increase substantially.
\end{abstract}

Keywords Glacier · Economic development - Meltwater · Manas River basin

\section{Introduction}

Observations have revealed that China's glaciers have been shrinking over the past halfcentury (Yao et al. 2004; Ding et al. 2006; Xiao et al. 2007; Li and Cheng 2008). The growth or decline of glaciers is determined by their mass balance, which is influenced by climate variables such as air temperature and precipitation (Kang et al. 2002; Shi 2008a, b). A study of several high-mountain glaciers in Asia showed that the equilibrium line altitude (ELA) is sensitive to variations in summer mean air temperature and annual precipitation

X. Tang $(\bowtie) \cdot$ L.-P. Xu $\cdot$ Z.-Y. Zhang

Geography Department of Natural Science, Shihezi University, Shihezi 832003,

People's Republic of China

e-mail: txling@sina.cn

X. Lv

Production and Construction Corps in Xinjiang, Key Laboratory of Oasis Ecological Agriculture,

Shihezi 832003, People's Republic of China 
(Zhang et al. 1998). The ELA varied from 52 to $152 \mathrm{~m}$ in response to a mean summer air temperature variation of $1{ }^{\circ} \mathrm{C}$. Similarly, with a change of $100 \mathrm{~mm}$ in mean annual precipitation, the ELA varied from 9 to $85 \mathrm{~m}$ (Zhang et al. 1998). Significant ablation occurs when air temperatures are high, even if the high temperatures coincide with high levels of precipitation over the accumulation zone (Liu et al. 1999b; Li et al. 2003). Shi and Liu (2000) estimated that by 2100, glacier volume in China may be only 30-67\% than that of the present day. Xie et al. (2006) simulated scenarios in which temperatures warmed by $0.01,0.03$, and $0.05 \mathrm{~K} \mathrm{a}^{-1}$ and found that by the end of the twenty-first century, China's glaciated areas would decrease by 14,40 , and $60 \%$, respectively.

The Tianshan range extends through China, Kyrgyzstan, and Kazakhstan and contains approximately 16,000 glaciers covering a total of 15,416 km² (Liu 1995; Shi 2008a, b). These glaciers have been the target of much climate-related research in recent years (e.g., Li et al. 2006; Aizen et al. 2006; Bolch 2007; Kutuzov and Shahgedanova 2009; Narama et al. 2010). With global warming, most mountain glaciers, including those in the Tianshan, are in a state of rapid retreat (Haeberli et al. 2007; Hoelzle et al. 2007; Wu and Zhu 2008; Li et al. 2009; Bolch et al. 2010; Nie et al. 2010). In Xinjiang, located in China's arid continental interior, glaciers are an important freshwater source and vital for industrial and agricultural development in the district (Yang et al. 2007). Recently, the climate in Xinjiang has switched from warm and dry to warm and relatively wetter. Both temperature and precipitation have increased and the drought index has declined over the past 50 years (Yao et al. 2009). The Cold and Arid Regions Environmental and Engineering Research Institute of the China Academy of Science estimated that at the northern foot of the Tianshan over the next 20-40 years, small glaciers of about $1 \mathrm{~km}^{2}$ or less are at great risk of melting completely. Glaciers covering more than $5 \mathrm{~km}^{2}$ will suffer a high degree of ablation and retreat. Rivers whose headwaters are dominated by the outwash from these small glaciers will probably experience severe fluctuations in their average annual flow volume because they are sensitive to variations in glacier growth, decay, and meltwater production. Rivers in the Xinjiang district have various headwater sources, and the proportion of water contributed by different glacial sources also varies. Therefore, the responses of rivers in the Xinjiang Uygar Autonomous Region to future climate change will also vary (Zhai and Zhou 1997).

The northern foot of the Tianshan is a vital ribbon of economic development in the Xinjiang region. The central district of northern Xinjiang in the Manas River basin is a large oasis-irrigated area of great socioeconomic importance in the region. The climate of the Manas River basin is essentially arid, and there is a great concern and uncertainty regarding current water allocation and the future of water resources under global warming. The reliability and quality of water resources are also crucial for the future development of the region and its economic and ecological welfare. Future plans for the Manas River basin are currently focused on economic development. However, whether water will be available for such development must be closely monitored, especially considering the possibility of continued climate warming. Remote sensing is a useful tool for monitoring headwater glaciers and other water sources in the Manas River basin. Remote sensing allows for monitoring of large areas at relatively low costs and can aid in understanding how fragile resources, such as glaciers, might be affected by ongoing and future climatic changes.

\section{The Manas River basin}

The Manas River basin $\left(43^{\circ} 27^{\prime}-45^{\circ} 21^{\prime} \mathrm{N} ; 85^{\circ} 01^{\prime}-86^{\circ} 32^{\prime} \mathrm{E}\right)$ is located between the northern foothills of the Tianshan and the southern margin of the Junggar Basin. The southern part 
of the Manas River basin starts at the Eren Habirga Range and lies adjacent to Hejing County. The northern margin of the Manas River basin abuts the Gurbantunggut Desert. To the east, the basin starts at the Taxi River and ends in the west at the Bayingou River. The basin is $198.7 \mathrm{~km}$ from east to west and $260.8 \mathrm{~km}$ from south to north, with a total area of $2.43 \times 10^{4} \mathrm{~km}^{2}$. The basin is made up of approximately $1.1 \times 10^{4} \mathrm{~km}^{2}$ of mountainous terrain, $9.6 \times 10^{4} \mathrm{~km}^{2}$ of plains, and $3.5 \times 10^{4} \mathrm{~km}^{2}$ of sand dunes. The land surface within the basin slopes from southeast to northeast. The highest height above sea level is $5,242.5 \mathrm{~m}$, and the lowest is $256 \mathrm{~m}$. Land higher than 3,600 m amsl is covered with accumulated snow year round. The area covered by glacial ice is $1,037.68 \mathrm{~km}^{2}$ (Fig. 1).

\section{Methodology}

(1) Glacier area: The glacier area is relatively simple to detect and measure via remote sensing. The size of a glacier is sensitive to the climate, and this is particularly true for the ratio of summer ablation (ice loss) to winter accumulation (growth) (Wang et al. 2008, 2011). We collected information regarding change in glaciated area in the Tianshan since 1960 (Table 1). To better understand variations on different spatial and temporal scales, it is important to identify the relationships between climatic variables and the mechanisms of changes in glacier size (Ren 1988; Hu 2004; Ding et al. 2006; Li et al. 2010a).

Our primary information sources were published data of the annual percentage change in glaciated surface area (Ding et al. 2006; Wang et al. 2011). In China, most glaciers are in decline, and therefore, their annual change in surface area is negative. We modified a

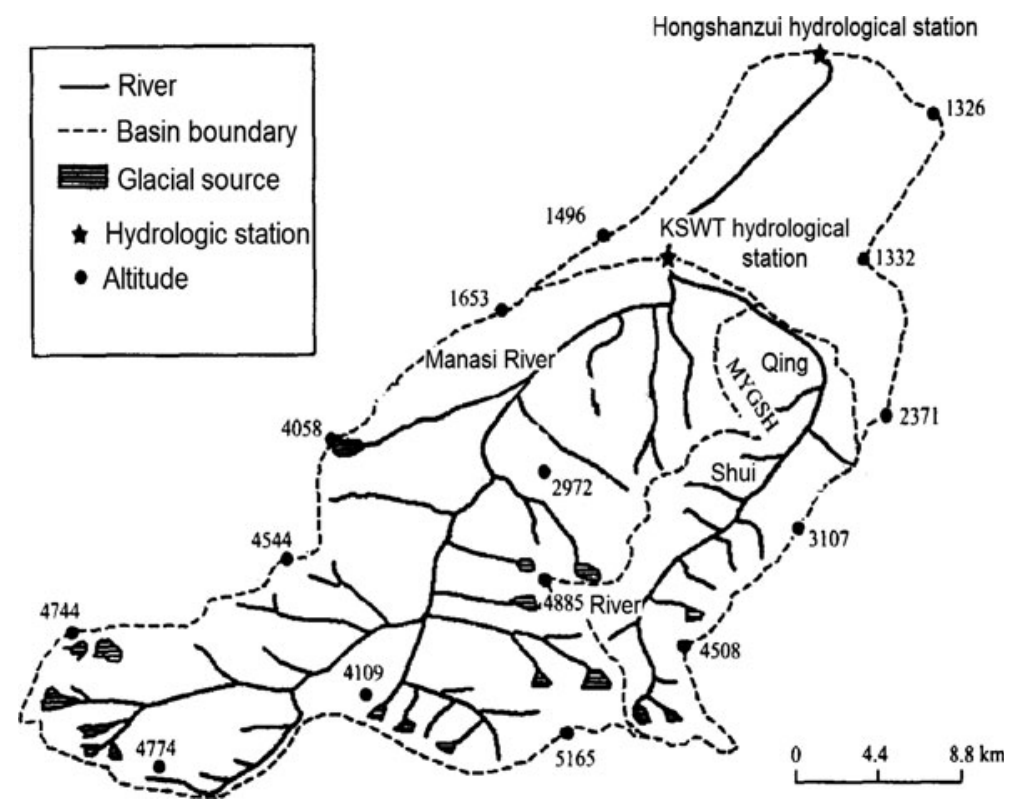

Fig. 1 The figure of Manas River water system of Manas River basin (in accordance with Yuan Yujiang, Yu Shulong, 2005) 
Table 1 Sources of data regarding change in glacial area in the Chinese Tianshan

\begin{tabular}{|c|c|c|}
\hline $\begin{array}{l}\text { Second-grade } \\
\text { drainage basin }\end{array}$ & $\begin{array}{l}\text { Third-grade } \\
\text { drainage basin }\end{array}$ & Study region \\
\hline $\begin{array}{l}\text { Junggar internal } \\
\text { drainages (5Y7) }\end{array}$ & $\begin{array}{l}\text { Yiwu River } \\
\text { (5Y71) } \\
\text { Baiyang River } \\
\text { (5Y72) } \\
\text { Manas River } \\
\text { (5Y73) } \\
\text { Ebinur Lake } \\
\text { (5Y74) }\end{array}$ & $\begin{array}{l}\text { Northern slope of Karlik Range (Wang et al. 2009), northern } \\
\text { slope of Bogda Range (Li et al. 2010a), Urumqi River (Kang } \\
\text { 1996; Chen et al. 1996; Li et al. 2010a), Toutun River (Li et al. } \\
\text { 2010a; Kang 1996), Santun River (Kang 1996), Hutubi River } \\
\text { (Kang 1996), Kuytun River (Li et al. 2010a), and Sikeshu River } \\
\text { (Liu et al. 1999a, b) }\end{array}$ \\
\hline
\end{tabular}

model that was originally established by Wang et al. (2011) to calculate an area-weighted mean growth rate. We used this area-weighted growth rate to assess the vulnerability of Tianshan glaciers. The area-weighted shrinking rate is

$$
\frac{\Delta S}{S_{0}}=\sum_{i=0}^{n}\left(\frac{S_{i}}{\sum_{i=0}^{n} S_{i}} \frac{\sum_{j=0}^{n} \Delta S_{i j}}{\sum_{j=0}^{n} S_{0 i j}}\right)
$$

where $i$ is the order number of units in this study, $j$ is the order number of references for each unit, $S_{0 i j}$ is the glacier area at the initial status $\left(\mathrm{km}^{2}\right), \Delta S_{i j}$ is the variation of glacier area $\left(\mathrm{km}^{2}\right), S_{i}$ is the total area of glaciers in the unit which is acquired from the GIC $\left(\mathrm{km}^{2}\right)$, $i, j=1,2,3, \ldots$ Annual percentages of area changes of glacier's acreage in any statistical unit since 1960 could be acquired with the method of interpolation:

$$
\operatorname{APAC}_{i}=\frac{\sum_{j=0}^{n} \frac{\Delta S_{i j}}{\Delta t_{i j}}}{\sum_{j=0}^{n}\left[S_{0 i j}+\left(t_{0 i j}-1960\right) \frac{\Delta S_{i j}}{\Delta t_{i j}}\right]}
$$

Annual percentages of area changes of glacier's acreage in the entire Manas River:

$$
\mathrm{APAC}=\frac{\sum_{i=0}^{n}\left\{S_{i} \frac{\sum_{j=0}^{n} \frac{\Delta S_{i j}}{\Delta_{i j}}}{\sum_{j=0}^{n}\left[S_{o i j}+\left(t_{o j}-1960\right) \frac{\Delta S_{i j}}{\Delta t_{i j}}\right]}\right\}}{\sum_{i=0}^{n} S_{i}}
$$

(2) Single-element regression analysis was applied to climate data for the Xinjiang Uygur Autonomous Region obtained from the Climate Information Center. This analysis was conducted to examine the data for linear trends between runoff and precipitation (Li et al. 2011). Single-element analysis and areal interpolation are widely used in climatic research on mountain areas, such as for the Qilian (Jia et al. 2008) and Hengduan ( $\mathrm{Li}$ et al. 2010b) mountain regions.

We used images taken at four different times for our remote-sensing analysis. The images were from the Landsat Multispectral Scanner (MSS) taken in 1964, the Landsat Thematic Mapper (TM) taken in 1983, the China-Brazil Earth Resources Satellite (CBERS) taken in 2006, and Landsat Enhanced Thematic Mapper taken in 2000. MSS (1964) used the artificial colors of 421 wavebands to make a compound image. The remote-sensing images 
taken in 1983, 2000, and 2006 used 432 waveband colors. Erdas 9.2, ArcGIS 9.3, and Photoshop 8.0 were used to digitize the images and examine topographic relationships.

\section{Variations in glacier area in the Manas River basin during the past 50 years}

Western China has become warmer over the past 50 years (from 1960 to 2010) as the Earth's mean air temperature has increased by an average of $0.2{ }^{\circ} \mathrm{C}$ per decade. Approximately $82 \%$ of the glaciers in the Manas River basin receded during this period (Yao et al. 2004; Ding et al. 2006; Wang et al. 2011). Nearly, all of the glaciers on the northern slopes of the Tianshan showed continual retreat, and $69 \%$ of glaciers on southern slopes retreated. The area of glacier cover in the central Manas River basin decreased by $10 \%$ (Shi and Liu 2000).

Presently, glaciers cover $608 \mathrm{~km}^{2}$ of the Manas River basin and the glacier volume is $3.9 \times 10^{8} \mathrm{~m}^{3}$. Over the 40-year period from 1960 to 2001 , there has been a mean $0.41 \%$ reduction in the area covered by glaciers. Annual glacier runoff was estimated to reach a maximum of $4.42 \times 10^{10} \mathrm{~m}^{3}$ and is an essential water resource ( $\mathrm{Li}$ et al. 2010a, b).

Figure 2 and Table 2 show that glacier mass balance remained negative over the 46-year study period. Annual mass balance between 1960 and 1985 was $-84.5 \mathrm{~mm}_{\text {year }}{ }^{-1}$, whereas that between 1986 and 2006 was three times larger at $-328.4 \mathrm{~mm}_{\text {year }}{ }^{-1}$. Glacier runoff depth also increased from approximately $478.4 \mathrm{~mm} \mathrm{year}^{-1}$ between 1960 and 1985 to $836.6 \mathrm{~mm}_{\text {year }}{ }^{-1}$ between 1986 and 2006, a $74.8 \%$ increase. Clearly, the rapid warming and increased melting have caused the volume of meltwater runoff to increase.

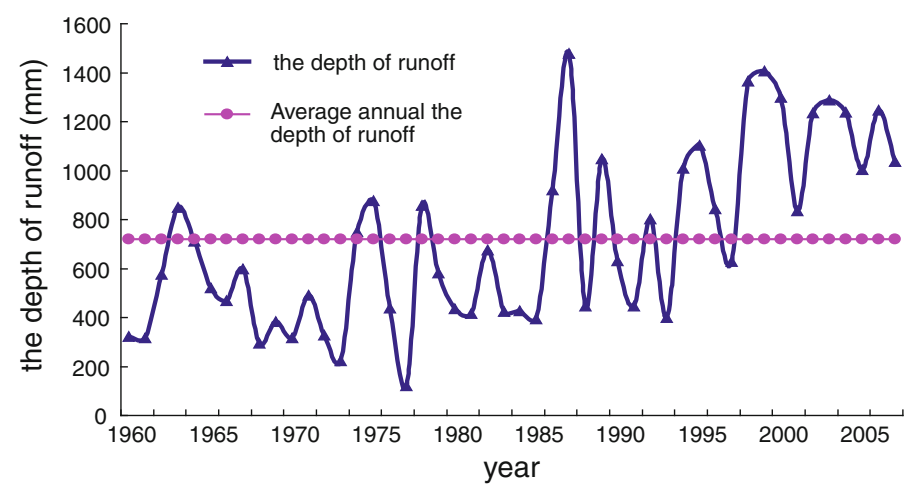

Fig. 2 Variation of the annual glacial meltwater runoff in Manas River basin during 1960 to 2006

Table 2 Melted percentage of glacier's acreage in Manas River basin

\begin{tabular}{clll}
\hline $\begin{array}{l}\text { Research } \\
\text { district }\end{array}$ & Age & $\begin{array}{l}\text { Average figure spot } \\
\text { melted rate }(\%)\end{array}$ & $\begin{array}{l}\text { Annual average } \\
\text { melted rate }(\%)\end{array}$ \\
\hline $\begin{array}{c}\text { Manas } \\
\text { River }\end{array}$ & $1964-1983$ & 0.0840776 & 0.0044250 \\
& $1983-2006$ & 0.281832 & 0.0169901 \\
& $1964-2006$ & 0.1984768 & 0.0054399 \\
\hline
\end{tabular}




\section{Changes in meltwater runoff in the Manas River basin from 1960 to 2010}

During a warm and dry year, glacier melting increases and the increased glacier runoff can compensate for decreased rainfall in the headwater area. Conversely, during a wet and cold year, glacial runoff decreases and does not contribute as much to the total outflow from the river valley. However, in 1982/1983, there was an anomalous trend in glacier development. During that year, the average glacier retreat was $-250 \mathrm{~mm}$, but both the meltwater and river data show an obvious positive trend.

Sensitivity analysis showed that the annual average temperature variation was $1{ }^{\circ} \mathrm{C}$ and that the glacier mass balance varied by about $300 \mathrm{~mm}$. This variation caused an $8 \%$ fluctuation in flow volume in the Manas River. As melting intensifies, runoff increases (the increase is about $19 \%$ ), with a peak volume at around May to June. Because peak runoff increases during the summer, it is possible that glacial lake outbursts may have contributed to the river outflow.

\section{Future glacier forecasts and their impact}

\subsection{Future climate change scenarios in the Manas River valley}

Both temperature and rainfall have shown increasing trends in the Xinjiang region in recent 50 years. In the period from 1960 to 2010, both temperature and rainfall increased, with average temperature rising by $0.2{ }^{\circ} \mathrm{C}$ and rainfall by $15 \mathrm{~mm}$ ( $\mathrm{Li}$ et al. 2011). These findings, combined with global climate model results from the Intergovernmental Panel on Climate Change (IPCC 2007), suggest that Xinjiang will have warmer temperatures and increased precipitation in the early twenty-first century. Drought and flooding are also expected to increase. Under the A1B scenario of the IPCC for the period 2007-2015 in the Manas River basin, temperature is predicted to rise by $1.19{ }^{\circ} \mathrm{C}$ and rainfall by $16.42 \mathrm{~mm}$.

\subsection{Future meltwater trend and its influence on water resources}

By 2050, the temperature in the southern Junggar Basin is predicted to be $2.1{ }^{\circ} \mathrm{C}$ higher, with summer warming of about $1.3{ }^{\circ} \mathrm{C}$. Of the glaciers in this area, 2,935 are less than $1 \mathrm{~km}^{2}$; these glaciers cover a total area of $807 \mathrm{~km}^{2}$ and hold ice reserves of $21.54 \mathrm{~km}^{3}$. With increased temperatures, these glaciers may melt completely (Bradley et al. 2009; Zhang et al. 2010). In the early twenty-first century, meltwater runoff of the Urumqi River is predicted to peak, reflecting the melting of most of the upland glaciers. Runoff will increase by $5-10 \%$ in the early twenty-first century and by $8-15 \%$ in the middle twentyfirst century. With the increase in glacier melting in the early to mid-twenty-first century (Zhang et al. 2009), the Manas River outflow will likely be greater than at present with an incremental increase of $10^{8} \mathrm{~m}^{3}$ year ${ }^{-1}$. The increased flow will be temporarily beneficial for economic development downstream. By 2050, however, the glacier runoff in the Manas River valleys will show decreasing trends (Table 3).

\subsection{Future melting trend and its response to rainfall}

In future climate change scenarios, rainfall and temperature in the Tianshan mountain area will continue to increase. Rainfall is forecast to increase by $0.45-1.56 \%$ and temperature by 0.49 to $-4{ }^{\circ} \mathrm{C}$ by 2050 . However, the flow volume will show large inter- and intra-annual variability of 
Table 3 The collection results of the future change trend of valley glacial meltwater in 3 kinds of climate scenarios (unit: $1 \times 10^{7} \mathrm{~m}^{3}$ )

\begin{tabular}{lc}
\hline River system & Manas River \\
\hline $2007-2010$ & $5.59-5.94$ \\
$2011-2020$ & $5.75-5.81$ \\
$2021-2030$ & $5.56-5.66$ \\
$2031-2040$ & $5.2-5.53$ \\
$2041-2050$ & $4.92-5.1$ \\
\hline
\end{tabular}

Table 4 Vulnerability index

\begin{tabular}{|c|c|}
\hline Vulnerability index & $\begin{array}{l}\text { Instruction (adapt to the technical countermeasure oriented of the } \\
\text { vulnerability of valley cryosphere) }\end{array}$ \\
\hline $\begin{array}{l}\text { Low vulnerability } \\
\quad(0.00-0.25)\end{array}$ & $\begin{array}{l}\text { Higher harmony between the development of economic society and } \\
\text { resource environment, bigger cryoconite cover, larger supply ratio of } \\
\text { glacial meltwater, good resource endowment condition and strong ability } \\
\text { against foreign influence, small variation influence on the environment, } \\
\text { stable eco-environment system }\end{array}$ \\
\hline $\begin{array}{l}\text { Middle vulnerability } \\
\quad(0.25-0.50)\end{array}$ & $\begin{array}{l}\text { The glacial cover is appropriate. However, as the glacier has low } \\
\text { temperature, high elevation, small change, and stable resource, so it has } \\
\text { the best resource environment condition. But the urban economy has weak } \\
\text { base and small ability against foreign influence, so its degree of resource } \\
\text { utilization and economic development mode has lower influence on the } \\
\text { environment. As a result, if the harmony is higher, human activity } \\
\text { intensity is small and the degree of resource development and utilization is } \\
\text { low as well as the evaluation indexes of resources and environment are the } \\
\text { highest }\end{array}$ \\
\hline $\begin{array}{l}\text { High vulnerability } \\
\quad(0.50-0.75)\end{array}$ & $\begin{array}{l}\text { Small glacial cover, low meltwater ratio, poor adjustment ability, obvious } \\
\text { influence of climate change. The resource condition is general. However, } \\
\text { as the urbanization speed is too quick and the pressure suffered by } \\
\text { resource environment is larger, so the resources reduce and ecological } \\
\text { environment worsens }\end{array}$ \\
\hline $\begin{array}{l}\text { Extremely high vulnerability } \\
\quad(0.75-1.00)\end{array}$ & $\begin{array}{l}\text { There is no distribution of glaciers, and it is mainly snow permafrost valley. } \\
\text { Sensitive response to climate change, small regulation function, and } \\
\text { bigger water resource variation. It needs to be adjusted by artificial } \\
\text { facilities, such as water reservoir, and so on to meet the development of } \\
\text { the valley. The social economy of the valley is weak and its adjustment } \\
\text { ability is low }\end{array}$ \\
\hline
\end{tabular}

Risk estimate refers to this plan that carry out the risk estimate of economic development planning in Xinjiang, which is proposed by teacher Xiao about to apply climatic changes capacity training class on 8 November, 2011, I had amended parameter then adopt it

25-50\%, which will exacerbate flood and drought events in the valley. Glaciers in the Manas River valley respond mainly to variations in rainfall. In a scenario in which future rainfall is reduced by $20 \%\left(\sim 100 \mathrm{~mm}_{\text {year }}{ }^{-1}\right)$, the glacial area decreases by $1.5-8.6 \%$, glacier ice reserves decline by $1.8-9.8 \%$, and runoff increases by $6.6-17 \%$. In a scenario in which rainfall in 2050 decreases by $0.03 \mathrm{~mm}_{\text {year }}{ }^{-1}$, the glacier area shrinks by $2-12.5 \%$, volume is reduced by $3-13.3 \%$, and runoff is increased by $9.6-23.3 \%$.

\subsection{Regional vulnerability in the case of retreating glaciers}

We calculated water supply and demand and used single surrogate markers to calculate the vulnerability of water resources, agriculture, and ecosystems to changes caused by glacier 
retreat. Our climate change forecasts suggested that, as glacier melt, the Manas River basin region will become increasingly vulnerable to shortages in water resources, which will affect ecological and socioeconomic systems (Table 4).

6.5 Risk to planned socioeconomic development in the study area

\subsubsection{Estimation of risk}

To estimate the risk to planned socioeconomic development, we developed criteria for selecting risk factors. Factors were then selected and a risk evaluation index system was built, based on long-term changes in temperature, rainfall, and snowmelt in Xinjiang. We determined the degree, probability, and likely hazard of each climate variable's influence on main elements of the economy and the structure of society. We then evaluated each individual factor and the degree of risk to the whole of Xinjiang region and key areas.

\subsubsection{The technical scheme of evaluation estimate and selection of risk factor}

See Tables 5 and 6.

Table 5 The technical scheme of evaluation estimate and selection of risk factor (10 aspects)

\begin{tabular}{|c|c|c|c|c|}
\hline Main risk & Risk origin & Influence object & Consequence and influence & Weight \\
\hline $\begin{array}{l}\text { Reduce the safety } \\
\text { performance of } \\
\text { foundation } \\
\text { engineering }\end{array}$ & $\begin{array}{l}\text { Increase of } \\
\text { rainfall and } \\
\text { runoff }\end{array}$ & $\begin{array}{l}\text { Water } \\
\text { conservancy, } \\
\text { railway, road, } \\
\text { civil aviation, } \\
\text { communication }\end{array}$ & $\begin{array}{l}\text { Enlarge the security risk of the } \\
\text { engineering and influence } \\
\text { the safe operation of the } \\
\text { engineering }\end{array}$ & 0.15 \\
\hline $\begin{array}{l}\text { Reduce the standard of } \\
\text { flood prevention } \\
\text { project }\end{array}$ & $\begin{array}{l}\text { Appearance of } \\
\text { extreme } \\
\text { events }\end{array}$ & $\begin{array}{l}\text { Flood prevention } \\
\text { project and town } \\
\text { safety }\end{array}$ & $\begin{array}{l}\text { Reduce the standard of flood } \\
\text { prevention project and cause } \\
\text { great influence on the } \\
\text { economic society }\end{array}$ & 0.2 \\
\hline Aggravated drought & $\begin{array}{l}\text { Appearance of } \\
\text { extreme } \\
\text { events }\end{array}$ & $\begin{array}{l}\text { Agriculture and } \\
\text { animal } \\
\text { husbandry }\end{array}$ & $\begin{array}{l}\text { Increase drought degree or } \\
\text { drought area and cause } \\
\text { bigger influence on the } \\
\text { economic society }\end{array}$ & 0.05 \\
\hline $\begin{array}{l}\text { Aggravated } \\
\text { waterlogging }\end{array}$ & $\begin{array}{l}\text { Appearance of } \\
\text { extreme } \\
\text { events }\end{array}$ & $\begin{array}{l}\text { Agriculture and } \\
\text { animal } \\
\text { husbandry }\end{array}$ & $\begin{array}{l}\text { Increase waterlogging degree } \\
\text { or waterlogging area and } \\
\text { cause bigger influence on the } \\
\text { economic society }\end{array}$ & 0.05 \\
\hline $\begin{array}{l}\text { Aggravated soil } \\
\text { salinization }\end{array}$ & $\begin{array}{l}\text { Increase of } \\
\text { rainfall and } \\
\text { runoff }\end{array}$ & $\begin{array}{l}\text { Agriculture and } \\
\text { animal } \\
\text { husbandry }\end{array}$ & $\begin{array}{l}\text { Enlarge the degree of soil } \\
\text { salinization or its area and } \\
\text { cause certain influence on } \\
\text { the economic society }\end{array}$ & 0.05 \\
\hline $\begin{array}{l}\text { Serious water depletion } \\
\text { for the development } \\
\text { of agriculture and } \\
\text { animal husbandry }\end{array}$ & $\begin{array}{l}\text { Increase of } \\
\text { temperature } \\
\text { and irrigation } \\
\text { area }\end{array}$ & $\begin{array}{l}\text { Agriculture and } \\
\text { animal } \\
\text { husbandry }\end{array}$ & $\begin{array}{l}\text { Reduce production, abandon } \\
\text { cultivation, make land } \\
\text { desertification, and cause } \\
\text { great influence on the } \\
\text { economic society }\end{array}$ & 0.15 \\
\hline
\end{tabular}


Table 5 continued

\begin{tabular}{|c|c|c|c|c|}
\hline Main risk & Risk origin & Influence object & Consequence and influence & Weight \\
\hline $\begin{array}{l}\text { Serious water depletion } \\
\text { for the development } \\
\text { of non-zone natural } \\
\text { ecology }\end{array}$ & $\begin{array}{l}\text { Increase of } \\
\text { temperature } \\
\text { and squeeze } \\
\text { of water }\end{array}$ & $\begin{array}{l}\text { Ecological } \\
\text { environment }\end{array}$ & $\begin{array}{l}\text { Degrade non-zone natural } \\
\text { ecology and deteriorate } \\
\text { ecological environment as } \\
\text { well as seriously influence } \\
\text { the sustainable development } \\
\text { of economic society }\end{array}$ & 0.1 \\
\hline $\begin{array}{l}\text { Serious water depletion } \\
\text { for industrial } \\
\text { development }\end{array}$ & $\begin{array}{l}\text { Industrial } \\
\text { development } \\
\text { and increase } \\
\text { of } \\
\text { temperature }\end{array}$ & Industry & $\begin{array}{l}\text { Limit the scale of industrial } \\
\text { development and seriously } \\
\text { influence the development } \\
\text { speed of economic society }\end{array}$ & 0.1 \\
\hline $\begin{array}{l}\text { Aggravated water } \\
\text { depletion of living } \\
\text { water }\end{array}$ & $\begin{array}{l}\text { Increase of } \\
\text { population } \\
\text { and } \\
\text { temperature }\end{array}$ & $\begin{array}{l}\text { Urban residents } \\
\text { and rural } \\
\text { residents }\end{array}$ & $\begin{array}{l}\text { Low per capita water standard } \\
\text { and seriously influence the } \\
\text { development and stability of } \\
\text { society }\end{array}$ & 0.1 \\
\hline $\begin{array}{l}\text { Aggravated water } \\
\text { depletion for urban } \\
\text { development }\end{array}$ & $\begin{array}{l}\text { Enlargement of } \\
\text { town and } \\
\text { enhancement } \\
\text { of } \\
\text { temperature }\end{array}$ & $\begin{array}{l}\text { Urban } \\
\text { afforestation and } \\
\text { public welfare }\end{array}$ & $\begin{array}{l}\text { Limit urban development and } \\
\text { cause bigger influence on the } \\
\text { development speed of social } \\
\text { economy }\end{array}$ & 0.05 \\
\hline
\end{tabular}

Table 6 The grading standard of the degree of risk (4 grades)

\begin{tabular}{|c|c|c|c|}
\hline $\begin{array}{l}\text { Risk } \\
\text { level }\end{array}$ & Name & Features & Risk index \\
\hline 1 & $\begin{array}{l}\text { General } \\
\text { risk }\end{array}$ & $\begin{array}{l}\text { Risk possibility is small or even it happens, the loss caused by it is } \\
\text { smaller, which generally does not influence the development of } \\
\text { economic society }\end{array}$ & $\mathrm{RI} \leq 0.2$ \\
\hline 2 & $\begin{array}{l}\text { Bigger } \\
\text { risk }\end{array}$ & $\begin{array}{l}\text { The possibility of risk occurring is bigger or the loss cause by it is } \\
\text { bigger, but the loss is acceptable }\end{array}$ & $0.2<\mathrm{RI} \leq 0.5$ \\
\hline 3 & $\begin{array}{l}\text { Serious } \\
\text { risk }\end{array}$ & $\begin{array}{l}\text { The possibility of risk occurring is big and the loss caused by the risk } \\
\text { is large, which influences the development of social economy. The } \\
\text { loss caused after the risk occurring is serious, but the probability of } \\
\text { risk occurring is very small. Take effective measurement to } \\
\text { develop normally }\end{array}$ & $0.5<\mathrm{RI} \leq 0.8$ \\
\hline 4 & $\begin{array}{l}\text { Disaster } \\
\text { risk }\end{array}$ & $\begin{array}{l}\text { The possibility of risk occurring is big. Once the risk happens, } \\
\text { serious consequence will be caused and the project cannot bear it }\end{array}$ & $\mathrm{RI}>0.8$ \\
\hline
\end{tabular}

\subsubsection{The evaluation of risk degree in Manas River valley}

Because of global warming in Manas River valley, the risk brought by glacial melting is gradually increasing, but the risk level is not high. Before 1930s, it is a general risk, and after 1930s, it becomes bigger risk level (Table 7). 
Table 7 Computation of the risk index in Manas River

\begin{tabular}{lrlllll}
\hline Index & No. & \multicolumn{2}{l}{ Years } & & & Weight \\
\cline { 3 - 6 } & & 2020 & 2030 & 2050 & 2060 \\
\hline Foundation engineering & 1 & 0.14 & 0.20 & 0.31 & 0.37 & 0.15 \\
Flood prevention project & 2 & 0.23 & 0.28 & 0.38 & 0.43 & 0.20 \\
Drought disaster & 3 & 0.18 & 0.27 & 0.44 & 0.53 & 0.05 \\
Waterlogging disaster & 4 & 0.23 & 0.28 & 0.38 & 0.43 & 0.05 \\
Secondary salinization & 5 & 0.10 & 0.10 & 0.10 & 0.10 & 0.05 \\
Agriculture and animal husbandry & 6 & 0.16 & 0.32 & 0.60 & 0.74 & 0.15 \\
Ecology & 7 & 0.06 & 0.12 & 0.20 & 0.24 & 0.10 \\
Industry & 8 & 0.13 & 0.15 & 0.19 & 0.23 & 0.10 \\
Life & 9 & 0.05 & 0.06 & 0.07 & 0.08 & 0.10 \\
Urban & 10 & 0.04 & 0.05 & 0.06 & 0.07 & 0.05 \\
Integration & 11 & 0.14 & 0.20 & 0.31 & 0.36 & 1.00 \\
Risk level & 12 & General risk & General risk & Bigger risk & Bigger risk
\end{tabular}

\section{Conclusion}

(1) With rapid warming in this valley since the 1980s, runoff from melting glaciers has also increased rapidly. Glacial mass balance has been negative with the average mass balance from 1960 to 1985 being $-84.5 \mathrm{~mm} \mathrm{year}^{-1}$ and that from 1986 to 2006 being $328.4 \mathrm{~mm} \mathrm{year}^{-1}$. The average meltwater runoff depth from glaciers in the Manas River basin was $478.4 \mathrm{~mm}$ year $^{-1}$ from 1960 to 1985 and $836.6 \mathrm{~mm} \mathrm{year}^{-1}$ from 1986 to 2006.

(2) In the early and mid-twenty-first century, increased melting of glaciers will make the runoff from the Manas River $10^{8} \mathrm{~m}^{3}$ greater than at present. This increase will be temporarily beneficial to economic development in downstream areas. However, by 2050, the glacier runoff in the Manas River valley will decrease and the river will become one of the smallest along the northern slopes of the Tianshan.

(3) In a scenario for 2050 in which rainfall is reduced by $0.02 \mathrm{~mm} \mathrm{year}^{-1}$ (20\% reduction), the glacier area is predicted to decrease by $1.5-8.6 \%$, glacier volume will decrease by $1.8-9.8 \%$, and runoff of meltwater will increase by $6.9-17.1 \%$. If rainfall decreases by $0.03 \mathrm{~mm}_{\text {year }}{ }^{-1}$ (30\% reduction), the glacier area may shrink by $2.0-12.5 \%$, with a volume reduction of $3-13.3 \%$ and an increase in runoff of 9.6-23.3\%.

(4) Global warming is increasing the risk of glacier melting in the Manas River valley, but the risk level is not yet high. Until the 2030s, a general level of risk will exist, but after that period, the risk will become greater.

Acknowledgments This work was supported by the National 973 Key Project of China (2010CB951004) and the National Natural Science Foundation Project of China (41001020). We gratefully acknowledge funding for this research.

Open Access This article is distributed under the terms of the Creative Commons Attribution License which permits any use, distribution, and reproduction in any medium, provided the original author(s) and the source are credited. 


\section{References}

Aizen VB, Kuzmichenok VA, Surazakov AB et al (2006) Glacier changes in the central and northern Tien Shan during the last 140 years based on surface and remote-sensing data. Ann Glaciol 43(1):202-213

Bolch T, Menounos B, Wheate R (2010) Landsat-based inventory of glaciers in western Canada, 1985-2005. Remote Sens Environ 114(1):127-137

Bradley RS, Keimig FT, Diaz HF et al (2009) Recent changes in freezing level heights in the Tropics with implications for the deglacierization of high mountain regions. Geophys Res Lett 36:L17701. doi: 10.1029/2009GL037712

Chen J, Liu C, Jin M (1996) Application of the repeated aerial photogrammetry to monitoring glacier variation in the drainage area of the Urumqi River. J Glaciol Geocryol 18(4):331-336 (in Chinese)

Ding Y, Liu S, Li J et al (2006) The retreat of glaciers in response to recent climate warming in western China. Ann Glaciol 43(1):97-105

Haeberli W, Hoelzle M, Paul F et al (2007) Integrated monitoring of mountain glaciers as key indicators of global climate change: the European Alps. Ann Glaciol 46(1):150-160

Hoelzle M, Chinn T, Stumm D et al (2007) The application of glacier inventory data for estimating past climate change effects on mountain glaciers: a comparison between the European Alps and the Southern Alps of New Zealand. Global Planet Change 56(1/2):69-82

Hu R (2004) Physical geography of the Tianshan Mountains in China. China Environmental Science Press, Beijing, pp 1-14, 180-198 (in Chinese)

IPCC Report (2007) Climate change 2007: impacts, adaptation, and vulnerability. Summary for policymakers. Report of working group II of the intergovernmental panel on climate change. Cambridge University Press, Cambridge

Jia W, He Y, Li Z et al (2008) The regional difference and catastrophe of climatic change in Qilian Mt. Region. Acta Geograph Sinica 63(3):257-269 (in Chinese)

Kang E (1996) A study on changes of the glacier system and its runoff at the North Flank of the Tianger Mountain in the Tianshan Mountains. J Glaciol Geocryol 18(suppl):60-74 (in Chinese)

Kang E, Cheng G, Dong Z (2002) Glacier-snow water resources and mountain runoff in the arid area of Northwest China. Science Press, Beijing, pp 14-54 (in Chinese)

Kutuzov S, Shahgedanova M (2009) Glacier retreat and climatic variability in the eastern Terskey-Alatoo, inner Tien Shan between the middle of the 19th century and beginning of the 21 st century. Global Planet Change 69(1/2):59-70

Li X, Cheng G (2008) Cryospheric change in China. Global Planet Change 62(3/4):210-218

Li Z, Han T, Jing Z et al (2003) A summary of 40-year observed variation facts of climate and Glacier No. 1 at headwater of Urumqi River, Tianshan, China. J Glaciol Geocryol 25(2):117-123 (in Chinese)

Li B, Zhu A, Zhang Y et al (2006) Glacier change over the past four decades in the middle Chinese Tien Shan. J Glaciol 52(178):425-432

Li Z, He Y, Wang S et al (2009) Changes of some monsoonal temperate glaciers in Hengduan Mountains Region during 1900-2007. Acta Geograph Sinica 64(11):1319-1330 (in Chinese)

Li Z, Li K, Wang L (2010a) Study on recent glacier changes and their impact on water resources in Xinjiang, Northwestern China. Quat Sci 30(1):96-106 (in Chinese)

Li Z, He Y, Xin H et al (2010b) Spatio-temporal variations of temperature and precipitation in Mts. Hengduan Region during 1960-2008. Acta Geograph Sinica 65(5):563-579 (in Chinese)

Li Z, He Y, Wang C et al (2011) Spatial and temporal trends of temperature and precipitation during 1960-2008 at the Hengduan Mountains, China. Quatern Int 236(1/2):127-142

Liu C (1995) Glacier resources and distributive characteristics in the Central Asia Tianshan Mountains. J Glaciol Geocryol 17(3):193-203 (in Chinese)

Liu C, Kang E, Liu S et al (1999a) Study on the glacier variation and its runoff responses in the arid region of Northwest China. Sci China (Ser D) 42(Suppl.1):64-71

Liu S, Xie Z, Wang N et al (1999b) Mass balance sensitivity to climate change: a case study of Glacier No. 1 at Urumqi Riverhead, Tianshan Mountains, China. Chin Geogr Sci 9(2):134-140

Narama C, Kaab A, Duishonakunov M et al (2010) Spatial variability of recent glacier area changes in the Tien Shan Mountains, Central Asia, using Corona ( 1970), Landsat ( 2000), and ALOS ( 2007) satellite data. Global Planet Change 71(1/2):42-54

Nie Y, Zhang Y, Liu L et al (2010) Glacial change in the vicinity of Mt. Qomolangma (Everest), central high Himalayas since 1976. J Geog Sci 20(5):667-686

Ren B (1988) Existing glacier fluctuation and its relation to the climatical changes in China. J Glaciol Geocryol 10(3):244-249 (in Chinese)

Shi Y (2008a) Concise glacier inventory of China. Shanghai Popular Science Press, Shanghai, pp 1-205 
Shi Y (2008b) Glaciers and related environments in China. Science Press, Beijing, pp 42-51

Shi Y, Liu S (2000) Estimation on the response of glaciers in China to the global warming in the 21st century. Chin Sci Bull 45(7):668-672

Wang S, Xie Z, Li Q (2008) Comparison study of glacier variations in East and West Tianshan Mountains. J Glaciol Geocryol 30(6):946-953 (in Chinese)

Wang Y, Hou S, Liu Y (2009) Glacier changes in the Karlik Shan, eastern Tien Shan, during 1971/72-2001/ 02. Ann Glaciol 50(53):39-45

Wang S, Zhang M, Li Z et al (2011) Glacier area variation and climate change in the Chinese Tianshan Mountains since 1960. J Geog Sci 21(2):263-273

Wu Y, Zhu L (2008) The response of lake-glacier variations to climate change in Nam Co Catchment, central Tibetan Plateau, during 1970-2000. J Geog Sci 18(2):177-189

Xiao C, Liu S, Zhao L et al (2007) Observed changes of cryosphere in China over the second half of the 20th century: an overview. Ann Glaciol 46(1):382-390

Xie Z, Wang X, Feng Q et al (2006) Modeling the response of glacier systems to climate warming in China. Ann Glaciol 43(1):313-316

Yang Y, Chen R, Ji X (2007) Variations of glaciers in the Yeniugou Watershed of Heihe River Basin from 1956 to 2003. J Glaciol Geocryol 29(1):100-106 (in Chinese)

Yao T, Wang Y, Liu S et al (2004) Recent glacial retreat in High Asia in China and its impact on water resource in Northwest China. Sci China (Ser D) 47(12):1065-1075

Yao Y, Li H, Zhang B (2009) Glacier changes in the past 30 years at the east watershed of Mt. Tomor. Arid Land. Geography 32(6):828-833 (in Chinese)

Zhai P, Zhou Q (1997) The change of northern hemisphere snow cover and its impact on summer rainfalls in China. J Appl Meteorol Sci 8(2):230-235

Zhang Y, Fujita K, Ageta Y et al (1998) The response of glacier ELA to climate fluctuations on High Asia. Bull Glacier Res 16:1-11

Zhang G, Sun S, Zhao L et al (2009) The response of the Glacier No. 1 to the height change of the $0^{\circ} \mathrm{C}$ level in summer at the riverhead of the Urumqi River, Tianshan Mountains. J Glaciol Geocryol 31(6):1057-1062 (in Chinese)

Zhang G, Sun S, Ma Y et al (2010) The response of annual runoff to the height change of the summertime $0{ }^{\circ} \mathrm{C}$ level over Xinjiang. J Geog Sci 20(6):833-847 